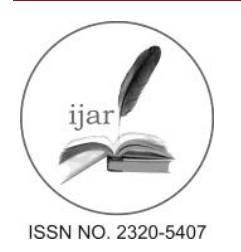

\author{
Journal homepage: http://www.journalijar.com

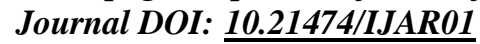

INTERNATIONAL JOURNAL

OF ADVANCED RESEARCH

RESEARCH ARTICLE

\title{
A PARADIGM SHIFT IN THE CARPET CRAFT BY SKILL UPGRADATION AND CAPACITY BUILDING TRAINING PROGRAMMES WITH SPECIAL REFERENCE TO THE STATE OF JAMMU AND KASHMIR.
}

\author{
Sheikh Imaan Ashraf ${ }^{1}$, Sheikh Numaan Ashraf ${ }^{2}$, Sibtain Manzoor $\mathrm{Hafiz}^{2}$. \\ 1. Research Scholar, The Business School, University of Kashmir. \\ 2. Department of Mechanical Engineering, University of Kashmir.
}

\section{Manuscript Info}

Manuscript History:

Received: 11 April 2016

Final Accepted: 13 May 2016

Published Online: June 2016

Key words:

Self-help groups; Mega carpet cluster project; Development commissioner handicraft; Business Development Services.

*Corresponding Author

Sheikh Imaan Ashraf.

\begin{abstract}
The Handicraft Industry, particularly the Carpet Craft Cluster is struggling for its progressive and prosperous existence.It is impacted by a lot of constraints including but not limited to identifying the cluster strengths, weaknesses, socio-economic environment. It also requires feasible steps to be taken for the overall sustainable growth of the cluster. The famous Handicraft industry including Carpet industry of Kashmir is a crucial economic contributor to the state of Jammu and Kashmir and provides livelihood to roughly 3.74 lakh people. However, in current times the industry is facing a lot of challenges due to the intervention of modern machinery and also increased competition from various countries.

Carpet Weaving is a significant activity in the handicraft family of the state of Jammu and Kashmir. This activity provides employment to a large chunk of population and substantially contributes to the exports of the state. In view of the insufficient economic returns from the trade in the past, this craft decayed and declined as master craftsmen of this activity were loath to pass on their skill and expertise to their children.

The Government of Jammu and Kashmir intervened by incorporating skill up gradation and capacity building training programmes at Government level to interested persons so that the manpower could be increased and thus maintain a right balance between demand and supply. The developmental approach has been adopted as a key strategy with the purpose of increasing the productivity, competitiveness as well as capacity of trainees. Major objectives of the study are to collect the information about the impact of such training programmes and assess the level of improvement in trainees after undergoing this training programme.
\end{abstract}

Copy Right, IJAR, 2016,. All rights reserved.

\section{Introduction:-}

Carpet Industry is one of the oldest industries in India. Carpet Weaving was brought to India by Moguls. Some of the majestic carpets were woven during this Mogul era. Over the period, the weaver has become an artist imbibing the magical exotic colors to the Indian carpets. Based on individualistic skill of the weaver, there is anesthetic touch of the coloring and beauty in the carpets. Over the period, various clusters have emerged in the northern parts of India. Initially, carpet weaving was done only at a few centers. Due to several historical reasons and availability of resources, carpet manufacturing spread across the northern India. Major centers have been Bhadohi, Agra, and Jaipur \& Kashmir. During the last few decades, hand-tufted carpets have emerged as one of the major categories. Due to proximity to Home furnishing products, Panipat has emerged as another major center for carpet manufacturing in India. 
Carpet Weaving is a significant craft activity in the craft family of the state of Jammu and Kashmir. This activity provides employment to a large chunk of people and substantially contributes to the exports of the state. Each kind of carpet has its own tradition, design and significance catering to different needs of customers. They have developed unique competitiveness in the respective categories. In view of the insufficient economic returns enjoyed by artisans in the past, this craft decayed and declined as the master craftsmen of this activity were loath to pass on their skill and expertise to their children. The Carpet industry of Kashmir is a crucial economic contributor to the state and to the country as well. However, the industry is facing a lot of challenges due to the intervention of modern machinery and also increased competition from various countries.

Despite the onslaught of modern technology based industrialization and the proliferation of modern looms in independent India, Handicraft continues to occupy a prominent place in the country's economy.

The Industry has seen a decline during the late 90s. However, carpet industry has recovered over the last few years. Many players in Industry doubt whether this recovery will be sustained or not.In J\&K, Handicraft activities occupy an important position in the economic structure of state. Being environment friendly, these activities are best suited to the state as they are more labour intensive and less capital intensive in nature, therefore, having scope for employment generation at a large scale, $J \& K$ Handicraft products have won worldwide fame for their attractive designs, functional utility and high quality craftsmanship. In absence of large scale industries in the state, handicrafts remained a key economic activity from times immemorial. Crafts like Shawls, Crewel, Namdha, Chainstitch, Wood carving, Paper machie, Kani shawls and Carpets hold a significant share in the overall production and export of the state. Silken Carpets in particular, constitute a specialty, having no parallel in quality and design at national level and, therefore, occupy an important position in the international market and contribute significantly towards the GDP of the country.

The handicraft sector of the state has great contribution towards foreign exchange earnings to the country and state in particular. Handicraft sector also plays an important role in the development and welfare of artisans. The sector makes conspicuous contribution in sustaining export trade of the state. The handicraft activities are especially carried out in Kashmir valley which is called the home of handicraft goods and has earned a unique place in the world of Handicraft Industry scenario.

The sector engages approximately 3.74 lakh artisans in manufacturing of handicraft products in J\&K state. The department also promotes sale of handicraft goods by organizing certain events including Export, Exhibitions and Craft Bazaars within and outside the state. It also organizes Exhibitions at international level, annually. Another activity of the department is to impart handicraft skills to about 8500 trainees annually through its 553 training centers (including 55 centers of Massive Carpet Scheme) in the state. The department also provides marginal subsidy on temporary basis at the rate of $100 \%$ for the first year , $66 \%$ for the $2^{\text {nd }}$ year and $33 \%$ for the $3^{\text {rd }}$ year to pass out trainees for formation of Cooperative societies.

\section{Skill upgradation and training programmes:-}

The Skill up gradation and Capacity building training courses has been conducted at different Artisan Development Centers (ADC's) established at certain identified locations within the state at convenient places within the cluster on temporary basis. The expert and technically trained people within and from outside the state delivered lectures and upgrade the skill level of participants.

During these programmes, the participants were trained in the areas as per the course content through the on job technical up gradation and orientation with guest experts from trade, industry, technical field and academia. In addition to above, practical/shop floor training on the subjects like Raw Material Testing, Carpet Designing through CAD, Raw Material Dyeing, and Finishing Process etc. formed a part of the training course followed by industrial visits and study tours in and outside the state as the case may be.

The training was provided to the artisans of carpet weaving who are actually involved in the manufacturing process of the craft. An adequate advertising and publicity was ensured within the identified cluster through use of print and electronic media especial in vernacular language to apprise the artisans of the proposed programme and its utility for development of a credible carpet industry. The main objectives of this training programmes provided with necessary technical and non-technical training include the following: 
* Up gradation of Skill of artisans to help them to work on new improved and market oriented designs and color combinations. This is being ensured through skill up gradation programmes with regard to different varieties/types of Raw materials, Quality of Raw material, Carpet designing with the help of CAD, Dyeing Technology, and Testing Equipment etc.

* To sensitize the workers about health friendly Modern Carpet loom and demonstrate its utility and benefits to the weavers.

* To make understand the weavers about methods of Dyeing Raw Material and sensitizing them about use and utility of vegetable dyes as compared to chemical/synthetic dyes besides orientation about clipping and washing of carpets.

* Sensitizing the weavers about sources of supply of Raw material and availability of market in different segments.

* Conducting awareness programmes about problems and prospects of Carpet trade in the international marketing scenario. This also includes awareness about standardization/certification and its benefits, Geographical Indication Act, (GI) and its benefits.

* Holding of orientation workshops for weavers for quality improvement, enhancing productivity, optimizing processes and quality benchmarking etc. Generating awareness among the workers about quality and its importance, consistency, Value addition, Process Improvements etc.

* Ensuring a comprehensive advertising and publicity policy to keep the workers informed about the developments in the industry from time to time.

* Conducting study tours of worker participants of skill upgradation programme within and outside the state to broaden the horizon of their practical exposure so that they can assimilate changes that are taking place at national and international levels.

* General awareness regarding schemes of various Departments/Ministries and the translation of these schemes into local languages. This shall also include awareness about availability of credit and finance and procedure for availing loan under credit schemes.

\section{Reasons for conducting such training programmes:-}

The Handicraft Industry, particularly the Carpet Craft Cluster is struggling for its progressive and prosperous existence and as such it requires a lot of support for identifying the cluster strengths, weaknesses, socio-economic environment and also the feasible steps to be taken for the overall sustainable growth of the cluster. The Carpet industry of Kashmir is a crucial economic contributor to the state and to the country as well. However, the industry is facing a lot of challenges due to the intervention of modern machinery and also increased competition from various countries.

Carpet Weaving is a significant craft activity in the craft family of the state of Jammu and Kashmir. This activity provides employment to a large chunk of people and substantially contributes to the export kitty of the state. In view of the insufficient economic returns enjoyed by artisans in the past, this craft decayed and declined as the master craftsmen of this activity were loath to pass on their skill and expertise to their children.

The Government of Jammu and Kashmir rose to the occasion and started a training programme at Government level to interested persons so that the manpower could be increased and thus maintain a right balance between demand and supply. A nominal number of people were also involved in weaving carpets within family setups as bonded laborers of middlemen and big traders. However, at all these levels, no effort was made to impart a comprehensive training to the artisans and upgrade their skill so that they can emerge as independent workers who could meet the challenges of change and could have know-how of all the activities right from manufacturing to dyeing, talim writing, design development washing and clipping of carpet etc.

A complete know-how of all these things could have helped the weaver to either perform auxillary services by themselves whenever needed or at least avail of better services from auxillary service providers. Moreover, in the ever changing industrial environment particularly in the post liberalization, privatization and globalization era, the weaver did not get exposed to the external environment so as to enable him to put in his efforts for a fair competition with other countries of the world.

The condensation of fragmented markets into a single market under the lexicon "Global Village" has brought about varied changes in the tastes and likings of buyers all over the world. There is a need to address such situation so as to meet the needs of the buyer according to his tastes within the ambit of preservation of cultural importance of arts 
and crafts so that we are in a position to withstand the pressures of present "buyers' market". Furthermore, the growing demand for the traditional hand knotted carpets all over the world cannot be met without corresponding increase in the production for which a motivated artisan is needed who no longer continues to be grinded under the exploitation of big traders. In this connection, the Governments at central and state levels have taken a number of measures and launched various schemes for the benefit of artisans so that they could fully involve themselves into the line and get the economic returns commensurate with the hard labour they put in.

As the human resource in the shape of artisans is the pivot round whom the success of the carpet industry revolves, so we need to upgrade their skills and build up their capacity so that this bedrock can be fortified for making the industry fit for the world market.

It has been observed that the carpet artisans from Srinagar and adjoining areas are good as far as elementary skill level is concerned (Carpet Weaving) but there is an urgent need to give them necessary inputs regarding various processes/activities directly or indirectly related with the carpet industry, having direct impact on the quality and commercial value addition etc. For this purpose, the government started a well-organized and structured capacity building and skill up gradation programme in the craft concentrated areas of Srinagar and its adjoining area. The proposed course not only empowers the artisans but will provide a window for their overall development in the present tough competition emerging in the international market.

The proposed capacity building and skill up gradation programmes helped the aspirants to emerge as independent craftsman through acquisition of integrated skills to generate self-employment in the sector and also to establish own production units. Also this training course generates adequate awareness regarding the quality, marketing trends, SHG formation and its benefits and the artisans was able to develop quality products which in turn would give them better economic returns. These initiatives by the institute would go a long way in the overall development of the carpet industry in general and the carpet artisans in particular as they are the ones who have been badly hit during last two decades.

\section{Methodology for study:-}

The data for the present study has been taken from both primary and secondary sources in Kashmir valley. The primary sources have been the offices of Development commissioner (Handicrafts), Indian Institute of carpet technology (IICT) and the outgoing trainees of various Artisan Development centers. A detailed questionnaire was used for primary sources who were contacted for the present study. Besides, the secondary sources including various government documentation, reports and books.

The primary and secondary data collected was compiled for the purpose of comprehensive analysis regarding impact of such training programmes.

\section{Impact of the programme:-}

In order to evaluate the impact Skill Up gradation and Capacity Building Training Programme, there was a proper research process to judge the efficiency of the training programme by taking a proper feedback from the artisans regarding the quality of training imparted so that the basic objective of the training programme is achieved.

During the interaction with the trainees it was observed that Skill up gradation and Capacity Building Training course benefitted majority of the Trainees in respect that they got awareness about SHG formation and its benefits, Marketing trends, various schemes etc. as they were unaware of modern technologies, Market interventions, Benefits of group formation etc. Also they redress many issues which seemed to be highly prevalent and a matter of concern. The main benefits they got from this Skill Up gradation and Capacity Building Training Programme include:-

\section{Personal Benefits:-}

The programme helped the artisan to got awareness regarding various technical as well as non-technical aspects like schemes of various departments/ministries as role of IICT, schemes of DC (H), schemes of MSME, schemes of NABARD etc. and how to avail benefits from these schemes and also get awareness about benefits of forming SHG's/Associations/Cluster. The Programme also helped them to learn new modern technologies like Dyeing Technology, Carpet Weaving/Finishing, Advantages of Modern Carpet Loom, and New Designs according to 
customer tastes, Importance of Quality and New Market Interventions. By this, these artisans promote their initiative to take advantage of all this so as to emerge as an independent tradesmen.

\section{Economic Benefits:-}

The programme makes the artisans competent to meet the challenges of change at the national and international level and build up their capacity to provide quality production to the market and also to broad based the production leading to increase in GDP. The industry can scale new heights as the skill up gradation was an eye opener for the artisans which broaden their horizon of knowledge with regard to various technical and non-technical aspects governing national and international trade of hand knotted carpets. As mentioned above, the programmes also makes the artisans aware of various incentives and schemes available with the government at central and state level and promote their initiative to take benefits of these schemes so that they can emerge as an independent tradesmen.

\section{Social Benefits:-}

The programme empowered the artisans with the skills in compatibility with the market demands and growing competition from different countries of the world without any distortion to the inherited cultural status of the carpet industry of Jammu and Kashmir. The increased involvement of artisans with different aspects of carpet trade and manufacturing helped them to be self-reliant and developed in them the interest to boost the scale of production which ultimately meets their physiological, social and esteem needs. The value addition to the skill and knowledge of artisans confer upon them recognition in the society where the level of skill was a determinant of their social importance.

\section{Industrial Benefits:-}

This programme upgrades and updates the skill and working knowledge of artisans and ensures quality production befitting the taste and likings of customers in different market segments. The target clusters was on the statistical information of IICT, Srinagar which would be essential for follow-up of training programmes/trainings, formation of self-help groups of artisans who can be linked to other schemes available with the central and state Government from time to time and also for policy formulation.

\section{Technical Benefits:-}

This programme upgrades and updates technical skill of artisans as the programme helps them to learn new modern technologies like Quality of Raw material, Methods of identification of raw material, Traditional and Modern methods of carpet Designing, Dyeing Technology, Natural and Chemical Dyes, Advantages of using Natural Dyes and their method of application, Do's and Don'ts of Carpet Weaving/Finishing, Advantages of Modern Carpet Loom, Weaving on Modern Carpet Loom and conducting of study tours of artisans of undergoing training courses in order to broaden the horizon of their practical exposure and assimilate the changes that are taking place at national and international levels.

\section{Acknowledgments:-}

This work was supported by the Indian Institute of Carpet Technology (IICT) in collaboration with Development Commissioner Handicrafts DC(H), Ministry of textiles, Government of India we place on record our sincere gratitude to the staff of IICT and $\mathrm{DC}(\mathrm{H})$ for generous help and cooperation.

\section{Conclusion:-}

During the research the data reveals that the skill up gradation and the capacity building training programme provided to artisans proved fruitful to them. Engagement of approximately 2700-3000 artisans in these training programmes helped in to flourish the trade. The training provided helped in connecting these artisans directly to the market thereby eliminating middlemen in the trade. Up gradation of Skill of artisans help them to work on new improved and market oriented designs and color combinations. This training programme helps the weavers to understand about methods of Dyeing Raw Material and sensitizing the weavers about sources of supply of Raw material and availability of market in different segments. By conducting study tours of worker participants of skill up gradation programme within and outside the state broaden the horizon of their practical exposure so that they can assimilate changes that are taking place at national and international levels. Skill up gradation programme provides artisans general awareness regarding schemes of various Departments/Ministries and availability of credit and finance and procedure for availing loan under credit schemes. 